\title{
Payment vs. Funding: The Law of Reflux for Today
}

\author{
Perry Mehrling*
}

\section{Working Paper No. 113}

January 28, 2020

\begin{abstract}
The analytical tension in post-Keynesian thought between the theory of endogenous (credit) money and the theory of liquidity preference, brought to our attention by Dow and Dow (1989), can be viewed through the lens of the money view (Mehrling 2013) as a particular case of the balance between the elasticity of payment and the discipline of funding. Further, updating Fullarton's 1844 "law of reflux" for the modern condition of financial globalization and marketbased credit, the same money view lens offers a critical entry point into Tobin's fateful 1963 intervention "Commercial Banks as Creators of "Money"" which established post-war orthodoxy, and also to the challenge offered by so-called Modern Money Theory.
\end{abstract}

Keywords: credit creation, financial intermediation, law of reflux

JEL Classifications: B2, E5

\footnotetext{
* Pardee School of Global Studies, Boston University. Comments by Marc Lavoie, Robert Guttman, and Steffen Murau are gratefully acknowledged.

https://doi.org/10.36687/inetwp113
} 
But from the point of view of the bank, it has acquired the security without giving up any cash; the counterpart, in its balance-sheet, is an increase in its liabilities. There is expansion, from its point of view, on each side of its balance-sheet. But from the point of view of the rest of the economy, the bank has 'created' money. This is not to be denied.

Hicks $(1989,58)$

We start with the idea of credit creation, specifically a swap of IOUs between a bank and myself involving a bank loan that is my IOU and a bank deposit that is the bank's IOU. Nothing could be simpler, and yet the mind rebels, especially the well-trained economist's mind, because this simple operation increases my purchasing power without decreasing anyone else's. It seems like alchemy, or anyway a violation of some deep conservation law. Real productive resources are the same as they were before, and the swap doesn't change that, does it?

Spending of the new purchasing power adds another layer of perplexity. If spending increases but real resources do not, then it seems logical that the increased spending must exhaust itself in higher prices - that is the intuitive appeal of the quantity theory of money. My purchasing power may increase, but everyone else's decreases because their money balances buy less. From this point of view, the alchemy of banking seems like a kind of theft, something to be deplored in the name of economic science and if possible outlawed in the name of the general good. 
The Keynesian tradition counters this monetarist intuition by questioning the assumption that real resources are fixed. ${ }^{1}$ If there is slack in the economy, then new spending most immediately draws down inventories, triggering new orders and new production, so mobilizing previously underutilized capacity, both capital and labor. In this counter intuition, my purchasing power increases and the consequence is that aggregate income increases. From this point of view, the alchemy of banking seems like a kind of widow's cruse, something to be treasured by economic science and if possible exploited in the name of the general good.

Apparently both of these intuitions have their appeal, since monetarists and Keynesians remain with us always. Maybe it is an empirical issue, about the amount of slack at a particular moment and where exactly it is? This is certainly the form the conversation has typically taken within the frame of the so-called neoclassical synthesis. But to my way of thinking, this empirical framing papers over a deeper and prior conceptual issue, which has nothing to do with the amount of slack in the economy and everything to do with the difference between payment and funding. This analytical distinction is not original to me, being basically the same as Graziani's (2003) distinction between initial finance and final finance for example. My contribution is the refinement and elaboration of that distinction within the money view balance sheet framework which, as will be seen, helps to clarify multiple long-standing debates as well as present controversies about the limits of money finance.

\footnotetext{
${ }^{1}$ I focus on the Keynesian tradition, but see also Schumpeter (1934) who locates the source of slack in innovation, and Lewis (1954) who emphasizes underemployed labor in the traditional sector of a dual economy. Henry Dunning Macleod $(1855,1856)$ appears to be the origin of this tradition, inspired as he was by the experience of Scottish free banking (Skaggs 2003).
} 


\section{Payment versus Funding}

A simple concrete example may help to fix ideas. Let us suppose that the swap of IOUs is a mortgage loan, and that I use my new purchasing power to buy your existing house. At the instant of sale, I swap one asset for another, and you swap the other way around, presumably because each of us prefers the asset held by the other. For present purposes, the important point to appreciate is that the alchemy of banking has made this sale possible, by creating new means of payment that you are willing to accept. After the sale, the bank's new IOU is owed to you instead of to me.

In fact, by accepting the bank's IOU as payment, you are funding the bank's loan to me, at least temporarily. Importantly, this is so even if you immediately shift the deposit from my bank to your own, provided that there is an interbank market where our banks can reverse the implied flow of reserves, as depicted in Figure 1. Now you are funding your bank's money market loan to my bank, and that loan is funding my bank's mortgage loan to me. Note that, in this stylized example, credit creation involves not only a new mortgage loan coupled with new bank deposits, but also an expansion of interbank lending. 


\section{Figure 1: Credit Expansion to Facilitate Payment}

My Bank

Me

You

Your Bank

\begin{tabular}{|c|c|c|c|c|c|c|c|}
\hline Assets & Liabilities & A & $\mathrm{L}$ & A & $\mathrm{L}$ & A & $\mathrm{L}$ \\
\hline \multirow[t]{3}{*}{+ mortgage } & + deposits & +deposits & +mortgage & & & & \\
\hline & & $\begin{array}{l}\text {-deposits } \\
\text { +house }\end{array}$ & & $\begin{array}{l}\text { +deposits } \\
\text {-house }\end{array}$ & & & \\
\hline & $\begin{array}{l}\text {-deposits } \\
+\mathrm{MM} \\
\text { borrowing }\end{array}$ & & & & & $\begin{array}{l}\text { +MM } \\
\text { lending }\end{array}$ & + deposits \\
\hline
\end{tabular}

The important point to appreciate from this example is that the apparent alchemy of banking is not so much about slack in the real economy as it is about the elasticity of payments in the banking system. Key to the alchemy is the fact that the newly created means of payment is indistinguishable from the old, and for that reason just as acceptable in payment. An important implication is that I am able to buy your house without any prior accumulation of liquid balances, and that you are able to sell your house without having to persuade any current holder of purchasing power to give up present liquidity. The alchemy of banking, or perhaps we should say the endogeneity of credit money, thus most fundamentally works to facilitate mutually improving bilateral trade.

But that's not the end of the story. You were willing to accept new purchasing power as means of payment for your house, and in doing so you wound up funding the bank's mortgage 
loan in the first instance. But by no means does that mean that you are willing to fund the loan for its entire term. Indeed, what matters after the moment of payment is not so much your own portfolio preferences as the preferences of the rest of the world to whom you pass along the new purchasing power as you spend it. The question is, when you are no longer funding the loan, who is and in what form? Figure 2 shows the three possible limiting cases. 
Figure 2: Reflux, Capital Funding, and Money Funding Compared

My Bank

$\mathrm{Me}$

ROW

ROW Bank

\begin{tabular}{|c|c|c|c|c|c|c|c|}
\hline Assets & Liabilities & A & $\mathrm{L}$ & A & $\mathrm{L}$ & A & $\mathrm{L}$ \\
\hline - & $\begin{array}{l}\text {-MM } \\
\text { borrowing }\end{array}$ & & & -deposits & -loan & $\begin{array}{l}\text {-loan } \\
\text { +mortgage } \\
\text {-MM } \\
\text { lending }\end{array}$ & -deposits \\
\hline
\end{tabular}

My Bank

$\mathrm{Me}$

ROW

ROW Bank

\begin{tabular}{|c|c|c|c|c|c|c|c|}
\hline Assets & Liabilities & A & $\mathrm{L}$ & A & $\mathrm{L}$ & A & $\mathrm{L}$ \\
\hline $\begin{array}{l}- \\
\text { mortgage }\end{array}$ & $\begin{array}{l}\text {-MM } \\
\text { borrowing }\end{array}$ & & & $\begin{array}{l}\text {-deposits } \\
\text { +mortgage }\end{array}$ & & $\begin{array}{l}\text {-MM } \\
\text { lending }\end{array}$ & -deposits \\
\hline
\end{tabular}

My Bank

$\mathrm{Me}$

ROW

ROW Bank

\begin{tabular}{|c|c|c|c|c|c|c|c|}
\hline Assets & Liabilities & A & $\mathrm{L}$ & A & $\mathrm{L}$ & A & L \\
\hline $\begin{array}{l}- \\
\text { mortgage }\end{array}$ & $\begin{array}{l}\text {-MM } \\
\text { borrowing }\end{array}$ & & & & & $\begin{array}{l}\text {-MM } \\
\text { lending } \\
\text { +mortgage }\end{array}$ & \\
\hline
\end{tabular}


In the first limiting case, the new purchasing power might be used simply to repay outstanding debt, so that at the end of the day there is no increase in aggregate credit at all. In the end, the banking system just replaces one loan with another; the initial expansion of bank credit facilitated the process, but then collapsed back down again. This limiting case is perhaps the closest to what those who first spoke about the law of reflux had in mind (Fullarton 1844, see Skaggs 1991 and more generally Le Maux 2012). In Fullarton's $19^{\text {th }}$ century world of short term commercial bills, there were always some bills maturing, so there was a direct channel for excess money balances to flow out of circulation by contraction of bank balance sheets on both sides. For modern conditions, however, we need to consider additional possible cases.

As a second limiting case we might imagine that the new purchasing power is used to buy a life annuity that is funded by investment in fixed income securities, perhaps even including the new mortgage having been sold by my bank, packaged with other similar securities, and transformed into a mortgage-backed security. In this case a new portfolio equilibrium is achieved by elimination of the interbank credit and the new purchasing power, but the new longterm credit remains, now funded by new long-term lending, all outside the banking system. As in the first case, the initial expansion of bank credit facilitated the process, but then collapsed back down again. The bank originated the mortgage, but it was ultimately funded elsewhere.

In the opposite limiting case, we might imagine instead that the new purchasing power remains fully in circulation, satisfying a new demand for liquid balances that has arisen for some reason or another. In that case we might imagine that the banking system continues to hold the mortgage, perhaps shifting it to where the new balances are being held so that interbank credit shrinks back to what it was originally even as the new mortgage loan and the new purchasing power remain. In this case there is no reflux of the new purchasing power, but the reason is that 
somehow the spread of that new purchasing power through the economy has had the effect of increasing demand for money balances. The new money did not disappear, but the excess supply of money did, because the demand for money grew into it.

All three of these limiting funding cases can be understood as instances of what Keynes $(1937,666)$ called the "revolving fund of liquid finance". Bank credit expands but then contracts again, and the entire thing is a balance sheet operation requiring no real resources. Even in the third case, holdings of the newly created money balances serve in effect as long term funding for the new long term credit. In all three cases, credit creation is fundamentally about a bank choosing to become unliquid in order that a buyer can become liquid, and then about traversing the gap to a new funding equilibrium. When the traverse is done, the "revolving fund of liquid finance" is restored, and the process can start again.

A key issue in this process is the role of asset prices, so far not mentioned but in fact the central focus of Keynes' article, as evidenced by its title "The 'Ex-Ante' Theory of the Rate of Interest”. Because the entire flux and reflux process is just a balance sheet operation, Keynes argued that the standard "savings-theory" of the interest rate needs to be replaced by a "liquiditytheory" of the interest rate. As the previous analysis has hopefully made clear, from the bank's point of view the interbank money market rate of interest is the initial (i.e. "ex ante") cost of funding the loan during the transition period from one funding equilibrium to another. That's the rate that a bank which has chosen to become unliquid must pay to another bank to recover its original reserve position in the event that the new purchasing power is transferred elsewhere. The liquidity theory of the interest rate must, in the first instance, be a theory of that interbank rate. 
In my reading, this 1937 Keynes is the Keynes that Sheila Dow embraces in "Endogenous Money Creation and Idle Balances" (Dow and Dow 1989), though without using my language of payments and funding. ${ }^{2}$ Liquidity preference, she emphasizes, determines asset prices as a markup over the money rate of interest, which is set as a policy variable by the central bank. To my mind, this position is fully consistent with the money view, so long as we appreciate that the central bank makes its policy rate effective by engaging in the interbank market, in effect offering its own balance sheet as a buffer to absorb any excess demand or supply at the chosen rate. Further, the larger dealer system, cognizant of its own liquidity position, then translates money market conditions into a set of asset prices, both bid and ask prices, that are consistent with the new funding equilibrium. In general, the new funding equilibrium will be a blend of the three limiting cases - part reflux, part capital funding, part money funding - and the movement of assets prices is part of the process that determines the proportions of the final blend.

In this way, the language of the money view helps to clear up an obscurity in Keynes that has long puzzled the post-Keynesian tradition (as Bibow 1995, Rochon 1997, Cesaroni 2001, de Carvalho 2002). Those familiar with this literature will have noticed that, by comparison to it, the present analysis simplifies matters by treating the case of financing the sale of an existing capital asset, rather than the case of financing the production of a new capital asset. In this way, we abstract from any direct effect on income and concentrate instead on the balance sheet operations involved, enabling us to show that the process underlying the "revolving fund of

\footnotetext{
${ }^{2}$ Dow's language apparently owes more to the circuitiste tradition of Graziani, Parguez, and others. See Graziani (2003), Parguez and Seccareccia (2000). My own "money view" approach similarly owes initial stimulus to encounter with the circuitistes, whom I first met in Aglietta (1979). See Mehrling (1996), written in 1990.
} 
liquid finance" has nothing to do with saving or investment, but instead involves merely the law of reflux, which operates to balance the elasticity of payments and the discipline of funding.

\section{The Old view versus the New View}

We turn now to clarification of a second obscurity, this one in postwar Keynesian orthodoxy, which has its origin in Tobin's 1963 "Commercial Banks as Creators of Credit." Produced for a volume celebrating the $100^{\text {th }}$ anniversary of the National Banking System, by the pre-eminent American Keynesian monetary economist, professor at Yale and author of the famous 1962 Economic Report of the President under President Kennedy, this paper more than any other marks the moment of transition from a purported "old view" to a purported "new view" of money, which fatefully involved also a shift away from Keynes' 1937 focus on the elasticity of payments toward instead focus on the discipline of ultimate funding (Tobin 1969). By focusing attention on the ultimate funding equilibrium, Tobin's new view in effect abstracted from both the flux of bank credit expansion and the reflux of subsequent contraction, and so also from the traverse between one funding equilibrium and another. He is interested only in final positions, and concerns himself therefore centrally with how asset prices change to make the new final position an equilibrium. In the new view, banks are just one financial intermediary among others, and bank deposits are just one funding liability among others, not particularly special and only able to remain in circulation subject to the portfolio preferences of wealth holders.

The apparent target of Tobin's paper was of course not Keynes (1937) nor even the Radcliffe Report (Committee on the Working of the Monetary system 1959) which had so recently emphasized the endogeneity of credit money. Rather his target was the simple-minded

\footnotetext{
${ }^{3}$ Compare Godley and Lavoie (2007, Ch. 13).
} 
monetarist policy proposal to limit monetary policy to a long run 3-4\% money growth rule, and specifically the idea to implement that rule by limiting reserve growth to $3-4 \%$ on the grounds that reserve growth translates mechanically into money growth by means of the so-called money multiplier. Tobin's paper explicitly mentions Shaw (1958) as the proponent of such a rule, but contemporaneous readers would have recognized that the real target was Milton Friedman (1960). Apparently Shaw was a more appealing target, insofar as his subsequent book Money in a Theory of Finance (Gurley and Shaw 1960) could, in Tobin's interpretation, be understood as the foundation stone of the "new view". Shaw changed his mind, Tobin is suggesting, and so should you.

Tobin seems to have understood the monetarist growth rule proposal mainly as an attempt to rein in the ability of banks to create what he calls "fountain pen money", new purchasing power forced into circulation by means of new lending or asset purchases paired with new deposit creation. For monetarists, reserve requirements played an essential role in constraining what would otherwise be a "widow's cruse" of uncontrolled expansion of bank credit and money. Tobin countered with the argument that the portfolio preferences of wealthholders would put a limit on the expansion of bank credit, even without reserve requirements, since any new money would have to be willingly held. For Tobin, reserve requirements are important not so much to rein in wanton money creation but rather because they introduce important frictions that give the monetary authority valuable leverage for short-run economic stabilization using monetary policy.

Here we find the origin of postwar American Keynesian orthodoxy, a view that elides the process of flux and reflux that underlies the shift from one funding equilibrium to another, and hence abstracts from exactly that aspect of banking that is special, namely the role of credit 
creation in directing the flow of new credit, and hence in directing the economy more generally. The elasticity of payments through the expansion of bank balance sheets is completely absent from Tobin, and post-Keynesian critics have been bemoaning its absence ever since, pointing to Tobin's difference from Keynes (1937) in this respect, albeit largely to no avail. As I say, Tobin's intended target was monetarism, and the payments approach to monetary analysis was merely unintended collateral damage, but collateral damage it most definitely was. Abstracting from the process of flux and reflux, and indeed from all the mechanics of the payments system, Tobin shifted attention to asset prices rather than bank lending decisions as playing the central role in directing the flow of new credit and hence the economy more generally. In Tobin's hands, banks are mere intermediaries, one among many and perhaps not even the most important since pension funds and insurance companies are arguably the more natural repository for long term equity and bonds that finance the capital development of the nation.

In addition to downgrading the "old view" of banks and bank credit, Tobin was equally concerned with upgrading the agency of government and government-issued "printing press" money. The widow's cruse of "fountain pen" money that monetarists fear so much is, according to Tobin, controlled well enough by portfolio preferences, but the essentially similar widow's cruse of government-issued "printing press" money is not, and that presents policy makers with an opportunity. In effect, for Tobin the law of reflux works for private money but not for public money. Why not? Here are Tobin's own words:

Evidently the fountain pens of commercial bankers are essentially different from the printing presses of governments... Once created, printing press money cannot be extinguished, except by reversal of the budget policies which led to its birth. 
The community cannot get rid of its currency supply; the economy must adjust until it is willingly absorbed. The 'hot potato' analogy truly applies. For bankcreated money, however, there is an economic mechanism of extinction as well as creation, contraction as well as expansion. If bank deposits are excessive relative to public preferences, they will tend to decline; otherwise banks will lose income. The burden of adaptation is not placed entirely on the rest of the economy. (Tobin 1963, 415).

Evidently Tobin is thinking of printing press money as "outside" money, an asset that is no-one's liability, in contrast to bank money which is "inside" or credit money. In this regard, he follows the lead of Gurley and Shaw (1960), but it should be noted that their distinction between outside and inside is not a fact about the world, simply an analytical device that they use as a way of emphasizing that government money is superior to bank money in the domestic hierarchy of money and credit. Banks cannot create government money and must furthermore stand ready to redeem bank money on demand in government money; this is the convertibility discipline that underlies the law of reflux that disciplines their fountain pens. In Tobin's hands, this same analytical distinction between outside and inside has the effect of implicitly consolidating the balance sheets of the Treasury and the Federal Reserve, and the further effect of abstracting from the fact that the central bank is indeed a bank, analogous to a commercial bank but at a higher level in the system.

Nevertheless, and notwithstanding Tobin, Figure 3 shows how the creation of "printing press" money can in fact be understood completely analogously to the creation of "fountain pen" money (as Figure 1), in both cases as the expansion of a bank's balance sheet. In the government 
case as in the commercial banking case, the first step is the quintessential act of banking alchemy, the creation of new purchasing power in order to facilitate a payment. (In Tobin's account, this first step is hidden from view by consolidation of the Treasury and Fed balance sheets.) In the second step, the government buys goods with the new money, and the seller deposits that new money in her bank. ${ }^{4}$ Observe that here, as in the commercial case, in the first instance it is the seller of the goods that is funding the (central) bank loan to the (government) buyer. In a final step, I show the commercial bank exchanging currency for a reserve account at the central bank, as the analogous operation to interbank lending in the commercial case; we might think of reserves paying interest on the margin whereas currency does not.

\section{Figure 3: Credit Expansion to Facilitate Payment}

$\begin{array}{lll}\text { Central Bank } \quad \text { Treasury } & \text { ROW }\end{array}$

\begin{tabular}{|c|c|c|c|c|c|c|c|}
\hline Assets & Liabilities & A & $\mathrm{L}$ & A & $\mathrm{L}$ & A & $\mathrm{L}$ \\
\hline \multirow[t]{3}{*}{ +Tbill } & +currency & +currency & +Tbill & & & & \\
\hline & & $\begin{array}{l}\text {-currency } \\
\text { +goods }\end{array}$ & & $\begin{array}{l}\text {-goods } \\
\text { +deposits }\end{array}$ & & +currency & 更 \\
\hline & $\begin{array}{l}\text {-currency } \\
\text { +reserves }\end{array}$ & & & & & $\begin{array}{l}\text {-currency } \\
\text { +reserves }\end{array}$ & \\
\hline
\end{tabular}

${ }^{4}$ The attentive reader will observe that purchase of new goods rather than an existing house will create income for the seller. We will however continue to abstract from that in order to maintain focus on the mechanism of flux and reflux. 
Figure 3 thus shows how, in the government case as in the commercial banking case, it is the elasticity of payments that makes the initial payment possible. But what about the discipline of funding? As in the commercial banking case, the seller of goods funds the loan in the first instance, but who funds the loan ultimately, and how exactly? Analogously to the commercial banking case, three limiting cases of reflux can be identified, as Figure 4.

Figure 4: Reflux, Capital Funding, and Money Funding Compared

Central Bank

Treasury

ROW

ROW Bank

\begin{tabular}{|l|l|l|l|l|l|l|l|}
\hline Assets & Liabilities & A & L & A & L & A & L \\
\hline & & +reserves & & -deposit & & -reserves & -deposit \\
-Tbill & -reserves & -reserves & -Tbill & & & & \\
\hline
\end{tabular}

Central Bank

Treasury

ROW

ROW Bank

\begin{tabular}{|c|c|c|c|c|c|c|c|}
\hline Assets & Liabilities & A & $\mathrm{L}$ & A & $\mathrm{L}$ & A & $\mathrm{L}$ \\
\hline -Tbill & -reserves & & & $\begin{array}{l}\text { +Tbill } \\
\text {-deposit }\end{array}$ & & -reserves & -deposit \\
\hline
\end{tabular}

Central Bank

Treasury

ROW

ROW Bank

\begin{tabular}{|l|l|l|l|l|l|l|l|}
\hline Assets & Liabilities & A & L & A & L & A & L \\
\hline & & & & & & & \\
\hline
\end{tabular}


The first limiting case is reflux of the new money as repayment for a debt. There are a number of possible channels, including bank repayment of central bank discount loans, but to achieve complete reflux we need private wealth holders repaying a debt to the Treasury, i.e. tax payment. Concretely we might imagine wealth holders writing a check to the IRS, which when cashed shifts reserves from the banking system into the Treasury's account at the Fed. In effect this operation reassembles the swap of IOUs that got things going in the first place, and the reassembled swap can then be cancelled as the two legs net out. In this case, the revolving fund of liquid finance is restored by, as Tobin himself puts it, a "reversal of the budget policies", i.e. fiscal contraction rather than fiscal expansion, which is to say taxes in excess of spending rather than spending in excess of taxes.

The second limiting case involves private wealthholders shifting out of money in order to hold the new long term debt directly. Concretely we might imagine wealth holders using their deposit holdings to buy Treasury bills from the Fed. Here again, the revolving fund of liquid finance is restored by a "reversal of budget policies", in this case monetary contraction rather than monetary expansion.

In the absence of fiscal or monetary contraction, there remains the third limiting case in which wealthholders willingly hold their new money balances in the new funding equilibrium, and it is this case that Tobin apparently takes to be the general one. In Figure 4, balance sheet entries for this case are completely empty because all of the adjustment takes place in the "rest of the economy" instead. Concretely, and consistent with the IS-LM framework dominant at the time Tobin was writing, we might imagine that the initial monetary expansion leads to lower interest rates, both because higher reserves push down the interbank rate and because lower rates on non-monetary assets are needed to make wealth holders content to hold the additional non- 
interest bearing money. Subsequently, lower interest rates may stimulate higher spending in those categories sensitive to the interest rate, and hence also higher equilibrium income. It is the higher income and the lower rate of interest that cause money demand to expand to absorb the new money supply.

Framing Tobin's argument in the language of payments and funding, flux and reflux, thus reveals the maintained assumption underlying his argument, namely that the government in effect blocks channels of fiscal and monetary reflux in order to maintain the new purchasing power in circulation. In effect, Tobin assumes that fiscal authorities refuse to allow wealth holders to dispose of excess money holdings by paying taxes, and that monetary authorities similarly refuse to let them buy central bank assets. That's why printing press money is a "hot potato".

What Tobin offers, in effect, is a peace time analogue to the war finance stratagem of blocked accounts, famously advocated by Keynes in How to Pay for the War (1940). In war time, workers' wages accumulate in accounts that cannot be spent until after the war is won, and even then only in releases carefully staged to prevent excessive upward price pressure. This however is a case of funding disequilibrium, politically acceptable only in war time. In peace time, by contrast, funding equilibrium is achieved by asset price changes, and the analogue to the staged release of blocked accounts is active macroeconomic management using fiscal and monetary policy. Instead of a 3 or 4 per cent money growth rule, year in and year out, in pursuit of price stability, Tobin wants to use open market operations to move the rate of interest around in the interest of economic stabilization more generally.

With regard to price stability more narrowly, Tobin insists that in the case of "fountain pen" money reflux operates sufficiently smoothly so as to ensure that there are no excess bank 
money balances floating around to put upward pressure on commodity prices. In the case of "printing press" money, however, despite the fact that reflux is blocked so that excess central bank money balances remain in circulation, asset prices move sufficiently to increase money demand pari passu, so once again there are no excess money balances floating around to put upward pressure on commodity prices.

The difference between the old view and the new view, it turns out, once we translate both into the language of payment and funding, is really the difference between private bank agency and central bank agency. Tobin's goal was to provide analytical support for money funding of fiscal expansion, in opposition to monetarism. Obviously he did not succeed in killing monetarism, but he definitely did succeed in shifting analytical attention from ex ante to ex post, from payments elasticity to funding discipline, from reflux as a dynamic process to portfolio equilibrium as the end result of that process, and from bank agency in credit allocation to government agency in monetary policy.

\section{Modern Money Theory}

Twenty years ago, when I was just starting the project that would become the money view, I was asked to write a review of Randall Wray's Understanding Modern Money (1998), the book that launched what has come to be known as the Modern Money Theory movement, today perhaps the most prominent version of post-Keynesian heterodoxy. Back then, I welcomed the assignment as an opportunity to consider where to position my own developing view relative to the existing post-Keynesian firmament (Mehrling 2000). As I reconstruct my thinking at the time, I had dedicated myself to development of a credit theory of money, and 
from that point of view I read Wray's neo-chartalism as an attempt instead to develop a monetary theory of credit. ${ }^{5}$ Hence my title, "Modern Money: Fiat or Credit?".

Since then, my thinking has developed quite a bit, and as a consequence I would today read Wray somewhat differently. Although he certainly insists on the fiat (vertical) character of government money, and the derivative (horizontal) character of private money - Wray (1998) focuses on the former while Wray (1990) focused on the latter--it is nevertheless eminently possible to reframe what he says about government money in credit terms analogous to commercial banking money, very much along the lines of the discussion of Tobin in the pages above.

Like Tobin, Wray consolidates the Fed and Treasury balance sheets and as a consequence sees a fundamental difference between "fountain pen money" and "printing press money", the former as credit money and the latter as fiat money. Also like Tobin, he wants to use control of the latter for the public good, specifically the achievement of full employment and price stability. Instead of buying goods, he wants the government to hire unemployed labor directly at a fixed wage that then becomes the nominal anchor for prices in general. But substitute "labor" for "goods" in Figure 3, and the money view translation of Tobin applies equally well to Wray. In both Tobin and Wray, the first step is credit creation through expansion of the central bank balance sheet, completely analogous to commercial bank credit creation for a private customer.

Where Wray differs from Tobin is not on the flux, but on the reflux (or "reserve drain" as he sometimes prefers). He has in mind that almost all of the newly issued money flows back to the government in payment of taxes, which is the first "reflux" limiting case in Figure 4 (Wray 1998, 23). Indeed, in his "taxes-drive-money" view, the imposition of taxes payable in the

\footnotetext{
${ }^{5}$ The distinction is due to Schumpeter $(1954,717)$ in a passage I reproduced as an epigraph to the review.
} 
government's money issue is key to supporting the value of that money issue. Taxes too low, and excess money that cannot find a way to reflux may instead go into higher prices. Taxes too high, and the result is deflation as taxpayers scramble to acquire scarce money balances, even as some will necessarily default since in aggregate new money balances are insufficient. For a given level of spending, government thus needs to find the right level of taxes. For Wray, the important point is that in general we might expect the right level of taxes to be strictly less than the given level of spending, because people want to hold back some of the new money issue to use for other purposes. Note that this "hoarding" of new money issue is the third "money funding" limiting case in Figure 4, the one that Tobin emphasizes.

Where Wray further differs from Tobin is by assuming that, instead of allowing asset prices to adjust to the new enlarged money supply, the central bank exogenously fixes the rate of interest and then defends that fix by trading new money for interest bearing government bonds. This is recognizably the second "capital funding" limiting case in Figure 4. Higher interest rates make bonds more attractive, so more reflux of the new money issue; lower interest rates make bonds less attractive, so less reflux. Because he consolidates the Treasury and Central Bank, Wray thinks of the original currency issue as simply fiat money, not the liability of a central bank, and the new interest bearing bond as nothing more than an interest bearing form of fiat money. Nevertheless, he explicitly recognizes that the operation of replacing the former with the latter is a form of reflux (p. 161).

Thus, unlike Tobin, Wray treats all three channels of reflux, indeed putting most emphasis on the first rather than the third. For him what is exogenous is price, both the price of labor and the rate of interest. What is endogenous is spending which depends on the amount of unemployed labor, but also taxes (to achieve price stability) and the quantity of money (to 
achieve funding equilibrium at the chosen rate of interest). In effect, Wray sees less difference between war finance and peace finance than does Tobin, and consequently more agency for government to achieve desirable social goals. "For example, during WWII, the US government was able to 'borrow' to finance 'massive deficits' (five times larger than President Reagan's deficits, relative to the size of the economy) at a short term interest rate of $3 / 8$ of 1 per cent." (p. 89) Like Tobin, Wray's Keynes is not so much vintage 1937 as it is vintage 1940, How to Pay for the War. And it is not so much a restoration of the "old view", with its emphasis on bank agency, as it is endorsement of Tobin's "new view" of government agency.

Both Tobin and Wray make a big deal of the difference between bank money and government money, emphasizing that the former is "inside" or credit money while the latter is "outside" or fiat money, fountain pen money versus printing press money. In both cases however, as we have seen, the big deal is not really about inside versus outside, but rather about emphasizing the use of monetary authority to achieve desirable social goals. In both cases, it is both possible and illuminating to reframe the argument in credit terms by treating the central bank and the Treasury as separate entities, and so to understand the central bank as in fact a bank, expanding and contracting its balance sheet in a process of flux and reflux, much like a commercial bank. Tobin insisted, against the monetarists, that we don't have to worry about private bank flux because reflux will discipline, and we don't have to worry about central bank flux because changing asset prices will absorb any excess supply. Going farther than Tobin, Wray in effect insists that we don't have to worry about central bank flux even if we fix the rate of interest exogenously and so prevent asset prices from changing, provided that government keeps the channels of reflux open that Tobin assumed were closed, both the fiscal channel (taxes) and the monetary channel (bond sales). 
In a sense, the story underlying the evolution of monetary thought from Keynes (1937) to Tobin (1963) to Wray (1998) is fundamentally about absorbing the implications of war finance. With the benefit of hindsight, we can see that state money, like private money, is essentially just a form of credit. As such, the regulatory mechanism of flux and reflux that polices the former is just as important, though it takes a different institutional form, for policing the latter. In both cases the elasticity of payment is the key resource for initial agency, and the discipline of funding is what replenishes that resource for future agency. Ex ante banks, and central banks, are agents of credit creation. Ex post banks, and central banks, are intermediaries between borrowers and money holders. The tension between the theory of endogenous (credit) money and the theory of liquidity preference is thus revealed to be the difference between the elasticity of payments and the discipline of funding. 


\section{References}

Aglietta, Michel. 1979. A Theory of Capitalist Regulation. London: New Left Books.

Bibow, Jorg. 1995. “Some reflections on Keynes's 'finance motive' for the demand for money." Cambridge Journal of Economics 19: 647-666.

Cesaroni, Giovanni. 2001. "The finance motive, the Keynesian theory of the rate of interest and the investment multiplier." European Journal of the History of Economic Thought. 8 No. 1 (Spring): 58-74.

Committee on the Working of the Monetary System. 1959. [Radcliffe] Report. London: HM Stationery Office.

De Carvalho, Fernando de Cardim. 2002. “On Keynes’s Concept of the Revolving Fund of Finance.” Pages 79-90 in Money, Macroeconomics, and Keynes, Essays in Honour of Victoria Chick, edited by P. Arestis, M. Desai, and S. Dow. Northampton, MA: Edward Elgar.

Dow, Alexander C. and Sheila C. Dow. 1989. "Endogenous Money Creation and Idle Balances." Pages 147-164 in New Directions in Post-Keynesian Economics, edited by John Pheby. Brookfield, VT: Edward Elgar.

Dow, Sheila C. 1993. Money and the Economic Process. Brookfield, VT: Edward Elgar.

Friedman, Milton. 1960. A Program for Monetary Stability. New York: Fordham University Press.

Fullarton, John. 1844. On the Regulation of Currencies. London: J. Murray. 
Godley, Wynne and Marc Lavoie. 2007. Monetary economics: an integrated approach to credit, money, income, production and wealth. $2^{\text {nd }}$ edition. New York: Palgrave Macmillan.

Graziani, Augusto. 2003. The Monetary Theory of Production. Cambridge UK: Cambridge University Press.

Gurley, John and Edward S. Shaw. 1960. Money in a Theory of Finance. Washington, DC: Brookings Institution.

Hicks, John R. 1989. A market theory of money. Oxford: Clarendon Press.

Keynes, J. Maynard. 1940. How to Pay for the War: a radical plan for the chancellor of the exchequer. London: Macmillan.

Keynes, J. Maynard. 1937. “The 'Ex-Ante' Theory of the Rate of Interest.” Economic Journal 47 No. 188 (December): 663-669.

Le Maux, Laurent. 2012. "The Banking School and the Law of Reflux in General." History of Political Economy 44 No. 4: 595-618.

Lewis, W. Arthur. 1954. "Economic Development with Unlimited Supplies of Labour." Manchester School 22 No. 2 (May): 139-191.

Macleod, Henry Dunning. 1855. The Theory and Practice of Banking, Vol. 1. London: Longman, Brown, Green, and Longmans.

Macleod, Henry Dunning. 1856. The Theory and Practice of Banking, Vol. 2. London: Longman, Brown, Green, and Longmans.

Mehrling, Perry. 1996. "The Relevance to Modern Economics of the Banking School View." Pages 330-340 in Money in Motion: the Post Keynesian and Circulation Approaches, edited by Ghislain Deleplace and Edward J. Nell. New York: St. Martin's Press. 
Mehrling, Perry. 2000. “Modern Money: fiat or credit?” Journal of Post Keynesian Economics 22 No. 3 (Spring): 397-406.

Mehrling, Perry. 2013. “The inherent hierarchy of money.” Pages 394-404 in Social Fairness and Economics, edited by Lance Taylor, Armon Rezai, and Thomas Michl. New York: Routledge.

Parguez, Alain and M. Seccareccia. 2000. "The credit theory of money: the monetary circuit approach.” Pages 101-123 in What is Money?, edited by John Smithin. London: Routledge.

Phillips, Chester A. 1920. Bank Credit, A Study of the Principles and Factors underlying Advances made by Banks to Borrowers. New York: Macmillan.

Rochon, Louis-Philippe. 1997. “Keynes’s Finance Motive: a re-assessment. Credit, liquidity preference and the rate of interest." Review of Political Economy 9 No. 3: 277-293. Schumpeter, Joseph A. 1934. The Theory of Economic Development. An Inquiry into Profits, Capital, Credit, Interest, and the Business Cycle. Cambridge, MA: Harvard University Press.

Schumpeter, Joseph A. 1954. History of Economic Analysis. New York: Oxford University Press.

Shaw, Edward S. 1958. "Money Supply and Stable Economic Growth.” Pages 49-71 in United States Monetary Policy, its contribution to prosperity without inflation. New York: American Assembly.

Skaggs, Neil. 1991. “John Fullarton's Law of Reflux and Central Bank Policy.” History of Political Economy 23 No. 3: 457-480. 
Skaggs, Neil. 2003. "H. D. Macleod and the Origin of the Theory of Finance in Economic Development." History of Political Economy 35 No. 3 (Fall): 361-384.

Tobin, James. 1963. “Commercial Banks as Creators of Credit.” Pages 408-419 in Deane Carson, ed. Banking and Monetary Studies. Homewood, Ill.: Richard D. Irwin.

Tobin, James. 1969. “A General Equilibrium Approach to Monetary Theory.” Journal of Money, Credit, and Banking 1 No. 1: 15-29.

Tobin, James and William Brainard. 1963. "Financial Intermediaries and the Effectiveness of Monetary Controls.” American Economic Review 52 (May): 384-386.

Wray, L. Randall. 1990. Money and credit in capitalist economies: the endogenous money approach. Brookfield, VT: Edward Elgar.

Wray, L. Randall. 1998. Understanding Modern Money: The Key to Full Employment and Price Stability. Northampton, MA: Edward Elgar. 